\title{
Which modality is the best choice in distal radius fractures treated with two different Kirschner wire fixation and immobilization techniques?
}

\author{
Cüneyd Günay, M.D., ${ }^{1}$ Özdamar Fuad Öken, M.D., ${ }^{2}$ Osman Yüksel Yavuz, M.D., ${ }^{3}$ \\ Sinem Hürsen Günay, M.D., ${ }^{4}$ Hakan Atalar, M.D. ${ }^{5}$
}

\begin{abstract}
'Department of Orthopaedic Surgery and Traumatology, Eskişehir Osmangazi University Faculty of Medicine, Eskişehir, Turkey ${ }^{2}$ Department of Orthopaedics and Traumatology, Ankara Numune Training and Research Hospital, Ankara, Turkey ${ }^{3}$ Department of Orthopaedic Surgery and Traumatology, Turgut Ozal University Faculty of Medicine, Ankara, Turkey ${ }^{4}$ Department of Anesthesiology and Reanimation, Eskişehir State Hospital, Eskişehir, Turkey ${ }^{5}$ Department of Orthopaedic Surgery and Traumatology, Gazi University Faculty of Medicine, Ankara, Turkey
\end{abstract}

\begin{abstract}
BACKGROUND: The aim of the study was to investigate whether the number and position of Kirschner (K)-wires, and the manner and duration of immobilization influence radiologic and functional outcomes of distal radius fractures treated with percutaneous K-wire fixation.
\end{abstract}

METHODS: Ninety-two patients were included into the study with a mean follow-up period of 19.84 \pm 5.22 months (range, 13-34 months). In Group I, forty-five patients were treated with $3 \mathrm{~K}$-wires and supported with a volar semi-circular cast for the first 3 weeks followed by a removable splint for a further 3 weeks. In Group II, forty-seven patients were treated with 2 K-wires and supported with a below-elbow circular cast for 6 weeks postoperatively.

RESULTS: No significant difference in grip strength and DASH scores was found between the two groups. In clinical examination, significantly better functional results were determined in patients supported with a removable volar splint. At 6 weeks postoperatively, volar tilt, radial inclination, and radial length were significantly better in Group I compared to Group II (all $p$ values).

CONCLUSION: Tripod technique with $3 \mathrm{~K}$-wires is a safe and reliable procedure to achieve stability and good radiological results. The use of a removable splint also improves the functional outcomes in the treatment of both intra- and extra-articular distal radius fractures.

Key words: Distal radius fracture; functional outcome; Kirschner wires; percutaneous pinning; radiological outcome; treatment.

\section{INTRODUCTION}

Fractures of the distal radius are the most common of all orthopedic injuries accounting for nearly $20 \%$ of all fractures presenting in the Emergency Department. ${ }^{\left[{ }^{[}\right]}$First treatment principles involve obtaining an anatomic reduction and then

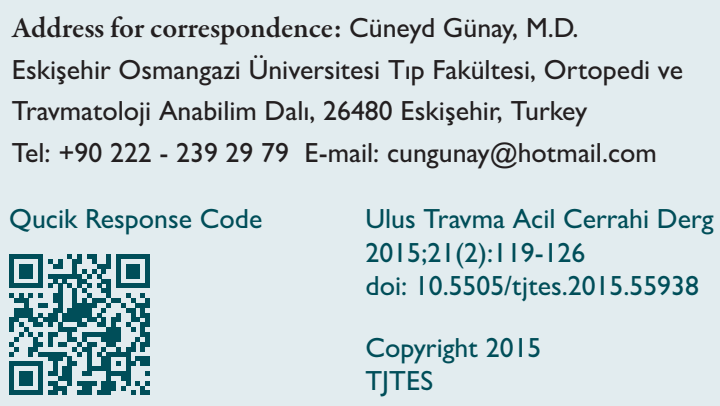

maintaining that reduction with appropriate methods of immobilization. In addition, immobilization for a short period and achieving good functional results are the main goals of management. ${ }^{[2]}$ Various techniques defined for the fixation of unstable distal radius fractures include open reduction and internal fixation, percutaneous pinning and plaster casting, external fixation, and combinations of all these. ${ }^{[3]}$ However, the optimal management method has not yet been established. ${ }^{[2,4]}$

Despite the development of different fixation devices for distal radius fractures, Kirschner $(\mathrm{K})$-wire fixation still plays an important role in the treatment of both stable and unstable fractures of the distal radius. K-wire fixation meets the criteria of biological osteosynthesis as a less invasive procedure that prevents soft-tissue damage. ${ }^{[5]}$ Additionally, fixation of $\mathrm{K}$-wires allows a shorter operation time, ease of hardware removal, excellent cosmetic outcomes, and early motion after removal. 
However, uncertainty remains about the indications for percutaneous pinning, the best technique to employ, and the extent and duration of immobilization. ${ }^{[2]}$ There are few studies in the literature comparing radiologic and functional outcomes of various K-wire techniques. The present study aimed to compare radiologic and functional outcomes of two different $\mathrm{K}$-wire fixation methods and immobilization techniques of extra- and intra-articular fractures of the distal radius.

\section{MATERIALS AND METHODS}

The institutional review board approved the chart review for this study, and informed consent was obtained from all patients. Between January $201 \mathrm{I}$ and January 20 I3, a total of two hundred and four patients were treated for a displaced distal radius fracture in our department. Of these, one hundred and twelve patients were treated with $\mathrm{K}$-wire fixation. The inclusion criteria were acute presentation within 24 hours of the injury and dorsally angulated unstable closed fractures of the distal radius in skeletally mature patients suitable for treatment with percutaneous K-wire fixation. Twenty patients excluded from the study included two that had previously sustained a distal radius fracture, six that had a high energy trauma, four that had bilateral fractures, three that died, and five that went to another hospital for further treatment. Exclusion criteria were open fractures, previously sustained distal radius fracture, high energy trauma, bilateral fractures, and loss to follow-up. Thus, the study was completed with ninetytwo of the one hundred and twelve treated patients. These patients, who underwent full assessment, were allocated to one of the two main groups depending on the number of $\mathrm{K}$ wires used for fixation. In Group I, $3 \mathrm{~K}$-wires and in Group
II, $2 \mathrm{~K}$-wires were used. The manner of postoperative immobilization, and the number of $\mathrm{K}$-wires used depended on the preferences of the surgeons (author I-CG, author 2-OFO). The mode of trauma in all patients was a simple fall onto the outstretched hand. All fractures were extra-articular (23-A type) or intra-articular (23-C type) as classified by the $\mathrm{AO}$ classification. The demographic data of the patients is presented in Table I.

In both groups, the patients were scheduled for operative treatment within 48 hours of injury. All operations were performed under general anesthesia with a prophylactic I g dose of intravenous antibiotics. With the patient in supine position on a radiolucent arm table, closed reduction was performed under fluoroscopic control in both groups by maintaining traction and counter-traction and correcting the components of the deformity. Two or three smooth K-wires, I.8-2.0 mm in diameter, were inserted through small stab incisions. In Group I, the first K-wire was inserted through the styloid process of the radius and the other through the dorso-ulnar border of the distal fragment with both wires engaging the opposite cortex. The third one was placed through the distal dorsal of the radius to the volar opposite cortex (Figs. Ia-c). In Group II, the first and second K-wires were inserted as in Group I (Figs. 2a-c)

The wires were protected with gauze. In both groups, the wires were bent outside the skin to avoid migration, and were cut to facilitate removal at six weeks postoperatively in the out-patient clinic. In both groups, active finger, elbow and shoulder mobilization exercises were started within the limits of comfort the day after surgery. A below-the-elbow

Table I. Desciption of patients data

\begin{tabular}{|c|c|c|c|}
\hline & Group I (3 K-wire) & Group II (2 K-wire) & Total \\
\hline \multicolumn{4}{|l|}{ Sex } \\
\hline Male & $9(20 \%)$ & $10(21.3 \%)$ & $19(20.7 \%)$ \\
\hline Female & $36(80 \%)$ & 37 (78.7\%) & $73(79.3 \%)$ \\
\hline Age & $62.22 \pm 12.47$ (range:4I-87) & $65.43 \pm 12.02$ (range:4I-89) & $63.86 \pm 12.28$ (range:4|-89) \\
\hline \multicolumn{4}{|l|}{ Side } \\
\hline Right & 35 (77.8\%) & $39(83 \%)$ & $74(80.4 \%)$ \\
\hline Left & $10(22.2 \%)$ & $8(17 \%)$ & $18(19.6 \%)$ \\
\hline Operation delay (day) & I.36 \pm 0.48 (range:I-2) & I. $23 \pm 0.42$ (range:I-2) & I.29 \pm 0.45 (range:I-2) \\
\hline Follow-up mean (month) & $21.40 \pm 5.89$ (range: $13-34)$ & |8.34 $\pm 4.0 \mid$ (range:|3-3|) & 19.84 \pm 5.22 (range: 13-34) \\
\hline \multicolumn{4}{|l|}{ Fracture type/AO } \\
\hline $23-A 2$ & $12(26.7 \%)$ & I3 (27.7\%) & $25(27.2 \%)$ \\
\hline $23-A 3$ & $13(28.9 \%)$ & $12(25.5 \%)$ & $25(27.2 \%)$ \\
\hline $23-\mathrm{Cl}$ & $7(15.6 \%)$ & II (23.4\%) & $18(19.6 \%)$ \\
\hline $23-C 2$ & $8(17.8 \%)$ & $6(12.8 \%)$ & 14 (I5.2\%) \\
\hline $23-\mathrm{C3}$ & $5(11.1 \%)$ & $5(10.6 \%)$ & $10(10.9 \%)$ \\
\hline
\end{tabular}



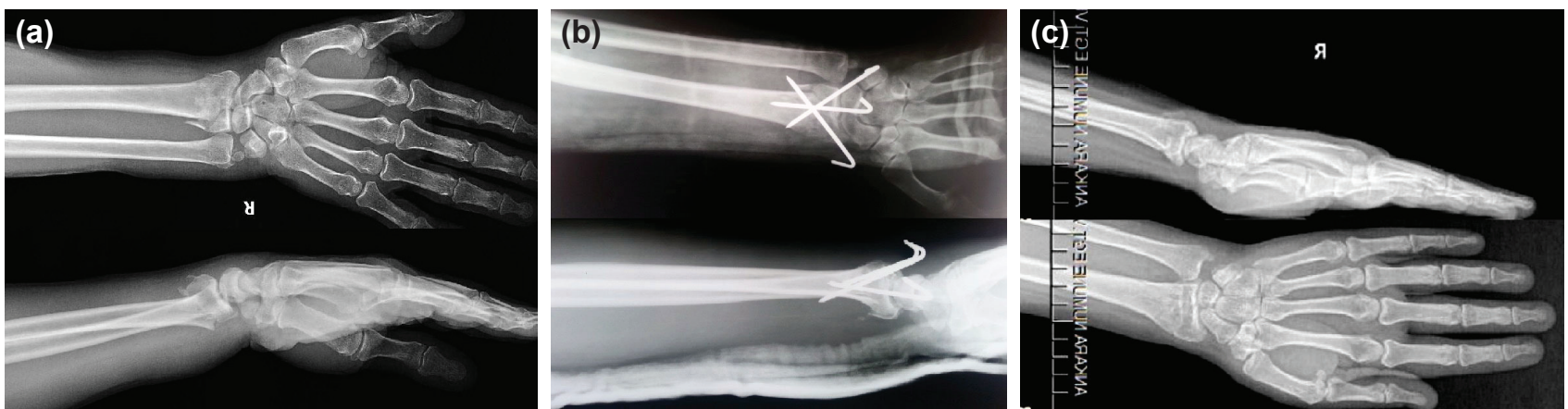

Figure 1. (a) Antero-posterior and lateral radiographs of a distal radius fracture in a 62-year-old male. (b) Tripod technique with $3-\mathrm{K}$ wires immediately postoperative. The fracture is supported via a semi-circular volar cast in the same patient. (c) X-rays at six weeks show the healed fracture without loss of reduction. A satisfactory outcome was achieved.
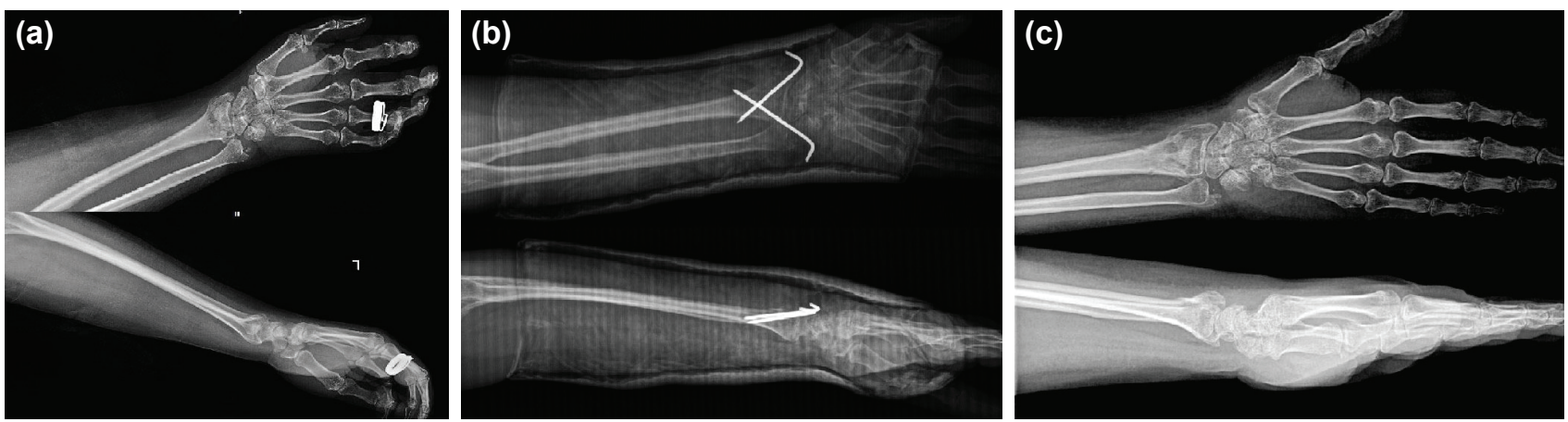

Figure 2. (a) Antero-posterior and lateral radiographs of a distal radius fracture in a 73-year-old female. (b) Fixation with $2-\mathrm{K}$ wires immediately postoperative. The fracture is supported via a below-the-elbow circular cast in the same patient. (c) Antero-posterior and lateral radiographs of the same patient at six weeks postoperatively.

semi-circular cast (in neutral position) was used for three weeks after the surgery, and then, a removable volar splint allowing mobilization several times a day was applied for a further three weeks. In Group II, a well- molded below-theelbow circular cast (in neutral position) was applied.

Physiotherapy after cast/splint removal was carried out routinely in both groups. Moreover, excessively tiring activity was forbidden for one month after the removal of the K-wires. Patients in the circular cast group (Group II) were discharged the day after surgery with confirmed good distal circulation of the fingers. Follow-up of the patients was performed at 2 , 4 and 6 weeks and at 3, 6 and 12 months after the procedure.

Radiographic and functional outcomes of all patients were assessed by one blinded physician who was not involved in the initial surgical treatment. The active range of motion (ROM) of the wrist including flexion, extension, pronation, supination, radial deviation, and ulnar deviation was measured using a standardized goniometer at six weeks and at one year postoperatively. Grip strength was measured using a Jamar dynamometer (Jamar, Preston, USA). The average Disabilities of the Arm, Shoulder, and Hand (DASH) scores ${ }^{[6]}$ and Grip strength were assessed in both groups at the I-year follow-up.

The radiographic study including volar tilt, radial length, and radial inclination was based on antero-posterior and lateral wrist radiographs taken on postoperative day one and at six weeks after K-wire removal, which was interpreted as the final result. The measurements were performed on the first postoperative day and at pin removal to assess any loss of reduction.

Statistical analyses were performed using SPSS (Version 13.0; SPSS Inc, Chicago, IL). Radiographic results (for independent variables) were analyzed between the two groups using the independent t-test. Functional parameters (for dependent variables) were analyzed using the paired sample t-test. Power analyses were also calculated using PS program by William D. Dupont and Walton D. Plummer (version 3.0.43). Statistical significance was set at $p<0.05$.

\section{RESULTS}

Both groups were similar in terms of age, gender, follow-up, fracture type distribution, injury mechanism, injury-surgery interval, fracture patterns, and injured side. There was no significant difference in the demographics of each group $(p>0.05)$ (Table I). Surgical procedure was performed after the first day of the injury in sixty-five $(71 \%)$ patients. Operation was delayed in twenty-seven $(29 \%)$ patients for anesthetic reasons. There were no problems in reduction and fixation 
Table 2. Radiographic outcomes between two groups

\begin{tabular}{|c|c|c|c|}
\hline & Group I & Group II & $\mathbf{p}$ \\
\hline & Mean $\pm S D$ & Mean $\pm S D$ & \\
\hline \multicolumn{4}{|l|}{ Radial inclination $\left({ }^{\circ}\right)$} \\
\hline Immediate after surgery & $22.78 \pm|.7|$ & $21.72 \pm 1.80$ & $<0.01$ \\
\hline At 6 weeks postoperatively & $21.18 \pm 1.69$ & $20.17 \pm 1.98$ & $<0.01$ \\
\hline Loss of radial inclination & $1.60 \pm 0.91$ & $1.55 \pm 0.95$ & $>0.05$ \\
\hline \multicolumn{4}{|l|}{ Radial length (mm) } \\
\hline Immediate after surgery & $13.33 \pm 1.33$ & $13.21 \pm 1.53$ & $>0.05$ \\
\hline At 6 weeks postoperatively & $11.93 \pm 1.62$ & $10.89 \pm 1.68$ & $<0.01$ \\
\hline Loss of radial length & $1.40 \pm 0.98$ & $2.32 \pm 1.18$ & $<0.001$ \\
\hline \multicolumn{4}{|l|}{ Volar tilt $\left({ }^{\circ}\right)$} \\
\hline Immediate after surgery & $12.29 \pm 1.25$ & $11.32 \pm 1.38$ & $<0.001$ \\
\hline At 6 weeks postoperatively & $|3.04 \pm| .3 \mid$ & $12.66 \pm 1.44$ & $<0.01$ \\
\hline Loss of volar tilt & $0.76 \pm 0.90$ & $1.34 \pm 1.10$ & $<0.01$ \\
\hline
\end{tabular}

in any patients, and there was no need to change the technique in any case. No loss of reduction was observed during the treatment period. By 6 weeks, progression of fracture healing was demonstrated by clinical and radiologic examination. No patient had any tendon rupture, vessel injury, radial sensory branch injury, median nerve compression or Sudeck's atrophy. One superficial pin track infection healed within one week with local pin care without administering antibiotics in Group I. All patients could be followed-up.

The alignment at the time of reduction was anatomical in both groups. Radiographic measurements of both groups in the early postoperative period and at six weeks postoperatively are presented in Table 2 . The mean radial length, immediately after surgery, was the same in both groups with no statistically significant difference. Mean radial inclination and mean volar tilt immediately after surgery were higher in Group I than in Group II $\left(22.78^{\circ} \pm 1.71^{\circ} / 21.72^{\circ} \pm 1.80^{\circ}, 12.29^{\circ} \pm 1.25^{\circ} /\right.$ I I. $32^{\circ} \pm 1.38^{\circ}$, respectively). These were statistically significant $(p<0.0$ I, $p<0.00$ I; power $>0.70$, power $>0.80$, respectively). At six weeks postoperatively, volar tilt, radial inclination, and radial length were significantly better in Group I compared to Group II. At six weeks, radial length was less in Group II than in Group I $(p<0.01$, power $>0.80)$. The mean loss in radial length at six weeks was higher and statistically significant in Group II compared to Group I ( $p<0.00$ I, power $>0.80)$. Radial inclination was higher in Group I than in Group II $(p<0.0$ I, power $>0.70$ ) at six weeks postoperatively. There were no differences in loss of radial inclination between the two groups. Immediately after surgery, the mean volar tilt in Group I was higher than in Group II ( $p<0.00$ I, power $>0.80)$. At six weeks, the mean volar tilt was increased in Group II $(p<0.0$ I). There was a statistically significant difference in loss of volar tilt in Group II $(p<0.0$ I, power $>0.70)$.
Mean active ROM at six weeks postoperatively and at the final follow-up, and mean increases between the two time intervals for both groups are shown in Table 3. Clinical examination of ROM in the injured wrist at six weeks after surgery showed significantly better flexion, extension, ulnar deviation, supination, and pronation (all $p$ values $<0.00$ l, power $>0.80$ ) in Group I than in Group II. Only radial deviation was statistically insignificant $(p=0.17)$. ROM parameters, except for radial deviation at the final follow-up, were better in Group I compared to Group II (all p values <0.00I, power>0.80). However, there was no difference in radial deviation between the two groups $(p=0.23)$. Mean increase in ulnar deviation at the final follow-up was higher in Group I ( $p<0.05$, power $>0.70)$, but mean increases for other parameters between the two groups were not statistically significant $(p>0.05)$. In clinical examination, significantly better functional results were determined in patients treated with $3 \mathrm{~K}$-wires. DASH scores and Grip strength measurements were minimally higher in Group I at the I-year follow-up, but there was no statistically significant difference (Table 3).

\section{DISCUSSION}

Distal radius fractures are common clinical problems which are generally treated conservatively. If this is not possible, then surgical fixation is required. ${ }^{[7]}$ Percutaneous pinning with K-wires was first recommended by Green as a simple and inexpensive procedure to provide additional stability. [8] Treatment with a plaster cast and percutaneous wires is considered common practice and can achieve a good functional outcome for specific and properly assessed fractures. ${ }^{[9]}$ Many pinning variations have been described in the literature. $[10,11,12,13]$ However, cross-pin fixation is advocated the most effective method for excellent stability of all major fragments. 
Table 3. Results of clinical examination, DASH score and Grip strength's of both groups

\begin{tabular}{|c|c|c|c|}
\hline & $\frac{\text { Group I }}{\text { Mean } \pm S D}$ & $\frac{\text { Group II }}{\text { Mean } \pm S D}$ & $\mathbf{p}$ \\
\hline \multicolumn{4}{|l|}{ Flexion $\left({ }^{\circ}\right)$} \\
\hline At 6 weeks postoperative & $70.44 \pm 4.16$ & $65.09 \pm 5.37$ & $<0.001$ \\
\hline At I year & $74.29 \pm 3.96$ & $69.64 \pm 6.22$ & $<0.001$ \\
\hline Mean increase & $3.84 \pm 2.44$ & $4.55 \pm 3.17$ & $=0.23$ \\
\hline \multicolumn{4}{|l|}{ Extension $\left({ }^{\circ}\right)$} \\
\hline At 6 weeks postoperative & $65.49 \pm 3.74$ & $60.64 \pm 4.91$ & $<0.001$ \\
\hline At I year & $68.60 \pm 3.84$ & $63.40 \pm 5.53$ & $<0.001$ \\
\hline Mean increase & $3.11 \pm 2.47$ & $2.76 \pm 2.93$ & $=0.54$ \\
\hline \multicolumn{4}{|l|}{ Radial deviation $\left({ }^{\circ}\right)$} \\
\hline At 6 weeks postoperative & $16 \pm 2.39$ & $15.21 \pm 2.98$ & $=0.17$ \\
\hline At I year & $|7.96 \pm 2.3|$ & $17.32 \pm 2.75$ & $=0.23$ \\
\hline Mean increase & $1.95 \pm 1.27$ & $2.10 \pm 1.73$ & $=0.63$ \\
\hline \multicolumn{4}{|l|}{ Ulnar deviation $\left({ }^{\circ}\right)$} \\
\hline At 6 weeks postoperative & $22.04 \pm 2.96$ & $19.28 \pm 3.11$ & $<0.001$ \\
\hline At I year & $23.62 \pm 3.22$ & $19.91 \pm 4.01$ & $<0.001$ \\
\hline Mean increase & $1.57 \pm 1.58$ & $0.63 \pm 1.91$ & $<0.05$ \\
\hline \multicolumn{4}{|l|}{ Supination $\left({ }^{\circ}\right)$} \\
\hline At 6 weeks postoperative & $73.22 \pm 2.65$ & $69.91 \pm 3.31$ & $<0.001$ \\
\hline At I year & $77.22 \pm 2.91$ & $73.68 \pm 3.96$ & $<0.001$ \\
\hline Mean increase & $4 \pm 2.45$ & $3.76 \pm 2.82$ & $=0.67$ \\
\hline \multicolumn{4}{|l|}{ Pronation $\left({ }^{\circ}\right)$} \\
\hline At 6 weeks postoperative & $73.24 \pm 2.77$ & $69.72 \pm 3.58$ & $<0.001$ \\
\hline At I year & $76.71 \pm 3.19$ & $72.32 \pm 4.39$ & $<0.001$ \\
\hline Mean increase & $3.46 \pm 2.78$ & $2.59 \pm 3.36$ & $=0.18$ \\
\hline DASH score/At I year follow-up & $\begin{array}{c}20.45 \pm 3.55 \\
\text { (range: } 14.00-28.50 \text { ) }\end{array}$ & $\begin{array}{c}20.38 \pm 3.48 \\
\text { (range: } 10.80-26.90 \text { ) }\end{array}$ & $=0.93$ \\
\hline Grip Strength $\left(\mathrm{kg} / \mathrm{cm}^{2}\right) /$ At I year follow-up & $\begin{array}{c}9.00 \pm 1.45 \\
\text { (range:6-12) }\end{array}$ & $\begin{array}{c}8.60 \pm 2.05 \\
\text { (range:5.10-12.50) }\end{array}$ & $=0.29$ \\
\hline
\end{tabular}

[14] There is scarce evidence as to the most appropriate number and placement of $\mathrm{K}$-wires and supporting techniques.

In radius fracture management, a satisfactory functional outcome is unlikely unless a good anatomical result is achieved. ${ }^{[15]}$ Most authors estimate loss of radial length as the most important radiologic parameter influencing the functional outcome, and it seems that any technique maintaining the radial length may attain better functional results. ${ }^{[3,13,16,17]}$ However, loss of radial length in terms of effects on functional outcome has been reported in various forms in the literature. ${ }^{[18,19,20,21]}$ In the current study, it was supposed that significant cortical and cancellous comminution in the distal radius on the dorsal and on the radial side may lead to late collapse due to resorption of the crushed bone. Therefore, an additional dorsal third K-wire was used to reduce the risk of collapse and regain better radiologic results. The use of the third Kwire reduced loss of radial length by about I $\mathrm{mm}$ in Group I compared to Group II. Therefore, the better functional results in Group I patients can be considered to be due to not only early movement but also to the lower reduction loss of radial length.

Many studies have shown that the number or position of K-wires does not influence radial inclination. ${ }^{[19,22,23,24]}$ In the present study, although radial inclination was better in Group I, there were no statistically significant differences between the groups in loss of radial inclination at follow-up. However, loss of volar tilt was higher in Group II. These results conform with those in the literature where the reduction loss 
in volar tilt is one of the most important factors of worse functional outcomes. ${ }^{[21,22,25,26,27]}$

The possibility of early functional treatment depends on the intraoperative influence of stability, complexity of the fracture pattern, quality of the bone, and age of the patient. ${ }^{[]}$ However, since K-wire fixation is not rigid, the patients often have to be immobilized in a plaster cast, generally for at least 4 to 6 weeks postoperatively. In the literature, the period of immobilization and the time of $\mathrm{K}$-wire removal have been reported as median six weeks. ${ }^{[24,28]}$ In two trials testing the duration of immobilization after surgery, no statistically significant difference was found in functional and radiological results. ${ }^{[29,30]}$ The method of limb immobilization following pinning is considered controversial among authors studying this topic. ${ }^{[2,31,32]}$ To the best of our knowledge, there has been no previous report in the English literature of an immobilization method as described here for Group I patients of this study.

In the current study, all operations were performed with a prophylactic I g dose of intravenous antibiotics. In contrast to this, some authors do not advocate the use of prophylactic antibiotics in the management of the distal radius fractures treated with $\mathrm{K}$-wire fixation. However, they have showed $2 \%$ infection rate in their study. ${ }^{[33]}$

In the present study, Grip strength was minimally higher in Group I compared to Group II, but this was not statistically significant as previously reported in other studies. ${ }^{[22,24,25]} \mathrm{A}$ meta-analysis study has demonstrated that external fixation may lead to greater recovery of grip strength, especially compared to fixation with locking volar plates. ${ }^{[34]}$ Since our treatment protocol resembles a kind of external fixation with K-wires and supporting devices, grip strength measurements may have showed higher scores in both groups.

Although DASH scores in Group I were minimally higher, there was no statistically significant difference between the two groups. Szyluk et al. have reported that DASH scores were good in their study group treated with K-wires and supported with a plaster cast. ${ }^{[35]}$ Many studies have demonstrated various ROM outcomes according to the supporting devices used and the duration. ${ }^{[24,25,28,36]}$ Milliez et al. ${ }^{[30]}$ have not recommended early functional treatment as a general concept. In contrast, Das et al. ${ }^{[26]}$ have reported that prolonged immobilization of the wrist for more than 3 weeks increases stiffness. Based on the results of the current study, if postoperative fracture fixation stability allows, then the use of a removable splint and encouragement of early wrist movement may improve functional outcome.

A wire diameter of $2.0 \mathrm{~mm}$ did not result in any significantly enhanced stability in a test model of unstable distal radius fractures when compared to a wire with a diameter of 1.6 $\mathrm{mm}$, with the K-wire being directed parallel and diagonal manner. Hence, the authors described the differences in ri- gidity according to pin size, and advocated that at least I.6 $\mathrm{mm}$ diameter K-wires were needed for stable cross-pin fixation. ${ }^{[14]}$ In both groups, similar cross-pin fixation (with I.8-2.0 $\mathrm{mm}$ K-wire) was applied. Biomechanical study could not be carried out for this case series because our study patients had both intra-articular and extra-articular fractures of the distal radius. In a biomechanical study, it is easy to obtain an extraarticular fracture model. In contrast, it is too difficult to obtain a standardized intra-articular fracture model for the distal radius fractures. Tsai et al., have showed that greater bone strength, higher wire stiffness, and longer wire contact length provide a more stable wire-bone construct, thus facilitating fracture reduction and bone union. In terms of entry point and insertion angle, surgical planning for the contact length has been more important than bony quality for stabilizing the whole wire-bone construct. ${ }^{[37]}$ From a biomechanical point of view for this study, in Group I patients (fixation with $3 \mathrm{~K}$ wires), the extent of the wire-bone contact plays a significant role in stability and reduction of a distal radius fracture.

In order to prevent median nerve compression and finger stiffness in Group II patients, we avoided placing the wrist in too much flexion. This may have been the reason that no Sudeck's atrophy was encountered during the follow-up period. Previous studies have reported that $\mathrm{K}$-wire fixation is a valid option only in $\mathrm{A} 2$ and $\mathrm{Cl}$ fractures, ${ }^{[21]}$ or in $\mathrm{A} 2, \mathrm{~A} 3$, and certain $C$ type fractures. ${ }^{[5]} \mathrm{K}$-wire fixation in elderly patients has been reported by some authors as not efficient ${ }^{[23,24]}$ while others have found no loss in reduction. ${ }^{[38]}$ In the present study, the results from at least one year follow-up seem capable of restoring judicious joint function, including in older patients. Two K-wire fixation and long immobilization with a circular rigid cast could not reduce loss of reduction in all three radiologic parameters. However, fixation with 3 $\mathrm{K}$-wires and the application of a semi-circular cast for three weeks postoperatively was more rigid, thus preventing loss of reduction. In addition, in Group I, using a removable splint after three weeks postoperatively allowed a much greater range of movement of the wrist and better functional results were obtained at the early and final follow-up.

The limitations of this study include that it was retrospective in design and there was no measurement of inter-observer errors in radiographic interpretation or functional evaluation. We acknowledge that obtaining standardized antero-posterior and lateral radiographs of the wrist with the forearm in an exact neutral position is difficult in clinical practice. Any forearm rotation may influence the accuracy of our radiological parameters. However, these errors in measurement would probably still be present in a prospectively designed study group. Furthermore, we only evaluated the loss of reduction between the first postoperative day and six weeks postoperatively. The injured wrists were not examined for any degenerative changes at the latest follow-up.

This study demonstrated that the use of an additional dor- 
sal K-wire was marginally superior in radiologic results. The third $\mathrm{K}$-wire acts as an additional support and maintains three points of fixation on each side of the fracture, which generally acts as a 'tripod chair'. It has also been shown that applying a semi-circular volar cast in neutral position followed by a removable splint allows for earlier rehabilitation without jeopardizing the fracture alignment. There is still a need for further investigation of the management methods of these fractures with large prospective randomized clinical trials, particularly to clarify the best use of K-wire stabilization and supporting techniques.

\section{Conflict of interest: None declared.}

\section{REFERENCES}

1. Simic PM, Weiland AJ. Fractures of the distal aspect of the radius: changes in treatment over the past two decades. Instr Course Lect 2003;52:185-95.

2. Handoll HH, Vaghela MV, Madhok R. Percutaneous pinning for treating distal radial fractures in adults. Cochrane Database Syst Rev 2007;18: CD006080.

3. Liporace FA, Adams MR, Capo JT, Koval KJ. Distal radius fractures. J Orthop Trauma 2009;23:739-48.

4. Lichtman DM, Bindra RR, Boyer MI, Putnam MD, Ring D, Slutsky DJ, et al. Treatment of distal radius fractures. J Am Acad Orthop Surg 2010;18:180-9.

5. Fritz T, Wersching D, Klavora R, Krieglstein C, Friedl W. Combined Kirschner wire fixation in the treatment of Colles fracture. A prospective, controlled trial. Arch Orthop Trauma Surg 1999;119:171-8.

6. Beaton DE, Wright JG, Katz JN; Upper Extremity Collaborative Group. Development of the QuickDASH: comparison of three item-reduction approaches. J Bone Joint Surg Am 2005;87:1038-46.

7. Fernandez DL. Closed manipulation and casting of distal radius fractures. Hand Clin 2005;21:307-16.

8. Green DP. Pins and plaster treatment of comminuted fractures of the distal end of the radius. J Bone Joint Surg Am 1975;57:304-10.

9. Matschke S, Marent-Huber M, Audigé L, Wentzensen A; LCP Study Group. The surgical treatment of unstable distal radius fractures by angle stable implants: a multicenter prospective study. J Orthop Trauma 2011;25:312-7.

10. DePALMA AF. Comminuted fractures of the distal end of the radius treated by ulnar pinning. J Bone Joint Surg Am 1952;24:651-62.

11. Rayhack JM, Langworthy JN, Belsole RJ. Transulnar percutaneous pinning of displaced distal radial fractures: a preliminary report. J Orthop Trauma 1989;3:107-14.

12. Ruschel PH, Albertoni WM. Treatment of unstable extra-articular distal radius fractures by modified intrafocal Kapandji method. Tech Hand Up Extrem Surg 2005;9:7-16.

13. Stein AH Jr, Katz SF. Stabilization of comminuted fractures of the distal inch of the radius: percutaneous pinning. Clin Orthop Relat Res 1975;108:174-81.

14. Naidu SH, Capo JT, Moulton M, Ciccone W 2nd, Radin A. Percutaneous pinning of distal radius fractures: a biomechanical study.J Hand Surg Am 1997;22:252-7.

15. Walton NP, Brammar TJ, Hutchinson J, Raj D, Coleman NP. Treatment of unstable distal radial fractures by intrafocal, intramedullary K-wires. Injury 2001;32:383-9.

16. Hollevoet N, Verdonk R. The functional importance of malunion in distal radius fractures. Acta Orthop Belg 2003;69:239-45.

17. Short WH, Palmer AK, Werner FW, Murphy DJ. A biomechanical study of distal radial fractures. J Hand Surg Am 1987;12:529-34.

18. Kelly AJ, Warwick D, Crichlow TP, Bannister GC. Is manipulation of moderately displaced Colles' fracture worthwhile? A prospective randomized trial. Injury 1997;28:283-7.

19. Kurup HV, Mandalia V, Shaju A, Beaumont A. Bicortical K-wires for distal radius fracture fixation: how many? Acta Orthop Belg 2007;73:2630.

20. Leung F, Ozkan M, Chow SP. Conservative treatment of intra-articular fractures of the distal radius--factors affecting functional outcome. Hand Surg 2000;5:145-53.

21. van Aaken J, Beaulieu JY, Della Santa D, Kibbel O, Fusetti C. High rate of complications associated with extrafocal kirschner wire pinning for distal radius fractures. Chir Main 2008;27:160-6.

22. Karnezis IA, Panagiotopoulos E, Tyllianakis M, Megas P, Lambiris E. Correlation between radiological parameters and patient-rated wrist dysfunction following fractures of the distal radius. Injury 2005;36:1435-9.

23. Kennedy C, Kennedy MT, Niall D, Devitt A. Radiological outcomes of distal radius extra-articular fragility fractures treated with extra-focal kirschner wires. Injury 2010;41:639-42.

24. Lenoble E, Dumontier C, Goutallier D, Apoil A. Fracture of the distal radius. A prospective comparison between trans-styloid and Kapandji fixations. J Bone Joint Surg Br 1995;77:562-7.

25. Azzopardi T, Ehrendorfer S, Coulton T, Abela M. Unstable extra-articular fractures of the distal radius: a prospective, randomised study of immobilisation in a cast versus supplementary percutaneous pinning.J Bone Joint Surg Br 2005;87:837-40.

26. Das AK, Sundaram N, Prasad TG, Thanhavelu SK. Percutaneous pinning for non-comminuted extra-articular fractures of distal radius. Indian J Orthop 2011;45:422-6.

27. Rodríguez-Merchán EC. Plaster cast versus percutaneous pin fixation for comminuted fractures of the distal radius in patients between 46 and 65 years of age. J Orthop Trauma 1997;11:212-7.

28. Strohm PC, Müller CA, Boll T, Pfister U. Two procedures for Kirschner wire osteosynthesis of distal radial fractures. A randomized trial. J Bone Joint Surg Am 2004;86-A:2621-8.

29. Allain J, le Guilloux P, Le Mouël S, Goutallier D. Trans-styloid fixation of fractures of the distal radius. A prospective randomized comparison between 6-and 1-week postoperative immobilization in 60 fractures. Acta Orthop Scand 1999;70:119-23.

30. Milliez PY, Dallaserra M, Defives T, el Ayoubi L, Thomine JM. Effect of early mobilization following Kapandji's method of intrafocal wiring in fractures of the distal end of the radius. Results of a prospective study of 60 cases. [Article in French] Int Orthop 1992;16:39-43. [Abstract]

31. Lozano-Calderón SA, Doornberg J, Ring D. Fractures of the dorsal articular margin of the distal part of the radius with dorsal radiocarpal subluxation. J Bone Joint Surg Am 2006;88:1486-93.

32. Roumen RM, Hesp WL, Bruggink ED. Unstable Colles' fractures in elderly patients. A randomised trial of external fixation for redisplacement. J Bone Joint Surg Br 1991;73:307-11.

33. Subramanian P, Kantharuban S, Shilston S, Pearce OJ. Complications of Kirschner-wire fixation in distal radius fractures. Tech Hand Up Extrem Surg 2012;16:120-3.

34 Wei DH, Poolman RW, Bhandari M, Wolfe VM, Rosenwasser MP. External fixation versus internal fixation for unstable distal radius fractures: a systematic review and meta-analysis of comparative clinical trials. J Orthop Trauma 2012;26:386-94.

35. Szyluk K, Jasiński A, Koczy B, Widuchowski W, Widuchowski J. Results of operative treatment of unstable distal radius fractures using percutaneous K wire fixation. Ortop Traumatol Rehabil 2007;9:511-9.

36. Stoffelen DV, Broos PL. Closed reduction versus Kapandji-pinning for extra-articular distal radial fractures. J Hand Surg Br 1999;24:89-91.

37. Tsai WC, Lin SC, Hsiao CC, Lu TW, Chao CK, Liu HC. Biomechanical 
analysis of distal radius fractures using intramedullary Kirschner wires. Med Eng Phys 2009;31:182-7.

38. Oshige T, Sakai A, Zenke Y, Moritani S, Nakamura T. A comparative study of clinical and radiological outcomes of dorsally angulated, unstable distal radius fractures in elderly patients: intrafocal pinning versus volar locking plating. J Hand Surg Am 2007;32:1385-92.

\section{KLINIIK ÇALIŞMA - ÖZET}

\section{Hangi yöntem iki farklı Kirschner teli ile tespit ve immobilizasyon teknikleri ile tedavi edilen distal radius kırıklarında en iyi seçimdir?}

\section{Dr. Cüneyd Günay, ${ }^{1}$ Dr. Özdamar Fuad Öken, ${ }^{2}$ Dr. Osman Yüksel Yavuz, ${ }^{3}$ Dr. Sinem Hürsen Günay, ${ }^{4}$ Dr. Hakan Atalar ${ }^{5}$}

${ }^{1}$ Esikişehir Osmangazi Üniversitesi Tıp Fakültesi, Ortopedi ve Travmatoloji Anabilim Dalı, Eskişehir;

${ }^{2}$ Ankara Numune Eğitim ve Araştırma Hastanesi, Ortopedi ve Travmataloji Kliniği, Ankara;

${ }^{3}$ Turgut Özal Üniversitesi Tıp Fakültesi, Ortopedi ve Travmatoloji Anabilim Dalı, Ankara;

${ }^{4}$ Eskişehir Devlet Hastanesi, Anesteziyoloji ve Reanimasyon Kliniği, Eskişehir;

${ }^{5}$ Gazi Üniversitesi Tıp Fakültesi, Ortopedi ve Travmatoloji Anabilim Dalı, Ankara

AMAÇ: Bu çalışmanın amacı, Kirschner (K) tellerinin sayısı ve pozisyonunun ve immobilizasyon şekli ve süresinin, kapalı olarak K-teli fiksasyonu ile tedavi edilen distal radius kırıklarının radyolojik ve fonksiyonel sonuçları üzerine etkisini araştırmaktır.

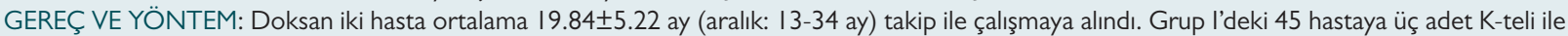
tespit sağlandı ve ilk üç hafta volar yarım alçı ile, sonraki üç hafta da ise çıkarılabilir splintle desteklendi. Grup Il'deki, 47 hasta ise iki adet K-teli ile tespit edildi ve ameliyat sonrası altı hafta dirsek altı sirküler alçıyla desteklendi.

BULGULAR: Her iki grup arasında kavrama gücü ve DASH skorları arasında önemli bir değişiklik yoktu. Klinik muayenede, daha iyi fonksiyonel sonuçlar, çıkarılabilir volar splint ile desteklenen hastalarda saptandı. Ameliyat sonrası altıncı haftada, volar tilt, radial inklinasyon ve radial yükseklik Grup I'deki hastalarda Grup Il'dekilerden daha iyi idi (tüm p değerleri <0.05).

TARTIŞMA: Tripod tekniğiyle üç K-teli uygulaması stabilite ve iyi radyolojik sonuçlar elde etmek için güvenli ve geçerli bir yöntemdir. Çıkarılabilir splint kullanımı, eklem içi ve eklem dışı distal radius kırıklarının tedavisinde fonksiyonel sonuçları geliştirmektedir.

Anahtar sözcükler: Distal radius kırı̆ğ; fonksiyonel sonuç; Kischner teli; perkütan pinleme; radyolojik sonuç; tedavi.

Ulus Travma Acil Cerrahi Derg 2015;2I(2):।19-126 doi: 10.5505/tites.20।5.55938 